\title{
PERAN EKOSISTEM MANGROVE BAGI MITIGASI PEMANASAN GLOBAL
}

\author{
Adilah Dinilhuda ${ }^{1)}$ Aji Ali Akbar ${ }^{1,2)}$ Jumiati $^{1)}$ \\ ${ }^{1}$ Program Studi Teknik Lingkungan Jurusan Teknik Sipil Fakultas Teknik Universitas Tanjungpura, Pontianak \\ 2) Correspondent author: aji.ali.akbar.2011@gmail.com
}

\begin{abstract}
ABSTRAK
Ekosistem mangrove merupakan ekosistem di daerah pesisir tropis dan subtropis yang berperan penting sebagai ekosistem pelindung pantai dari abrasi dan tsunami; produsen makanan bagi makhluk hidup pesisir serta ekosistem penyerap dan penyimpan karbon bagi ekosistem pesisir. Sebagai penyerap dan penyimpan karbon, mangrove dapat menyimpan karbon lebih banyak dari hampir semua ekosistem di bumi, sehingga ekosistem ini dapat berperan penting pula dalam upaya mitigasi pemanasan global. Mangrove dapat menyimpan karbon lebih banyak dari hampir semua ekosistem di bumi. Hampir 40\% dari biomassa pohon adalah karbon, dimana melalui proses fotosintesis dapat menyerap karbon dioksida dari atmosfer dan mengubahnya menjadi karbon organik (karbohidrat). Penyimpanan karbon pada ekosistem mangrove dapat dalam biomassa vegetasinya seperti dalam batang, daun, akar, umbi, buah dan lainnya. Estimasi potensi penyimpanan karbon dalam vegetasi mangrove sebagai mitigasi pemanasan global, menjadikan indikator penting bagi konservasi ekosistem mangrove.
\end{abstract}

Kata Kunci : Mangrove, Pemanasan Global, Dampak

\begin{abstract}
(The Role of Mangrove Ecosystems for Mitigating Global Warming) Mangrove are ecosystems in tropical and subtropical coastal areas that an important role as a coastal protective ecosystem from abrasion and tsunami; food producers for coastal living creatures as well as absorbent and carbon storage ecosystems for coastal ecosystems. As carbon absorbers and storage, mangroves can store more carbon than almost all forest ecosystems on earth, so this ecosystem can play an important role in mitigating global warming. Mangroves can be carbon sink ecosystems. Nearly $40 \%$ of tree biomass is carbon, which through photosynthesis can absorb carbon dioxide from the atmosphere and convert it to organic carbon (carbohydrates). Storage of carbon in mangrove ecosystems can be in vegetation biomass such as in stems, leaves, roots, tubers, fruit and others. The estimation of the potential of carbon storage in mangrove vegetation as a mitigation of global warming, makes it an important indicator for the conservation of mangrove ecosystems.
\end{abstract}

Keywords: Mangrove, Global Warming, Impact

\section{PENDAHULUAN}

Ekosistem mangrove berfungsi sebagaimana ekosistem hutan lainnya, yaitu penyerap karbon. Mangrove sebagai suatu ekosistem memiliki fungsi ekologi berupa pemecah ombak, mencegah abrasi, sebagai produsen makanan bagi makhluk hidup pesisir, serta upaya mitigasi pemanasan global. Mangrove dapat menyimpan karbon lebih banyak dari hampir semua hutan di bumi. Potensi penyerapan karbon dipengaruhi oleh kemampuan pohon untuk menyerap karbon melalui proses fotosintesis. Tumbuhan memerlukan Karbon dioksida $\left(\mathrm{CO}_{2}\right)$ pada proses fotosintesis yang akan diserap dari udara di atmosfer. Karbon yang diserap akan tersimpan dalam bentuk biomassa tumbuhan (Rachmawati et al., 2014).

Hampir $40 \%$ dari biomassa pohon adalah karbon, dimana pohon melalui proses fotosintesis menyerap karbon dioksida dari atmosfer dan mengubahnya menjadi karbon organik (karbohidrat) dan menyimpannya dalam biomassa tubuhnya seperti dalam batang, daun, akar, umbi, buah dan lainnya. Cara yang dapat digunakna untuk mengetahui simpanan karbon adalah dengan menghitung biomassa dari tumbuhan tersebut (Rahmah et al., 2015). Biomassa dari penyerapan karbon merupakan jasa hutan sebagai upaya pemulihan lingkungan dengan pengurangan $\mathrm{CO}_{2} \mathrm{di}$ udara. Kehilangan atau terdegradasinya ekosistem mangrove akan menjadi sumber karbon dalam jumlah besar untuk efek rumah kaca (Sondak et al., 2015).

Merosotnya penyerapan atau penyimpanan karbon dioksida berhubungan erat dengan biomassa tegakan, jumlah biomassa suatu kawasan diperoleh dari produksi dan kerapatan biomassa yang diduga dari pengukuran diameter, tinggi, berat jenis dan kepadatan setiap jenis pohon. Penurunan luas 
ekosistem hutan mangrove berhubungan dengan penyerapan dan penyimpan karbon guna pengurangan kadar $\mathrm{CO}_{2}$ di udara (Dharmawan dan Samsoedin, 2012). Pentingnya estimasi potensi penyimpanan karbon dalam vegetasi mangrove sebagai mitigasi pemanasan global, menjadikan isyarat agar melakukan konservasi terhadap ekosistem mangrove (Senoaji dan Hidayat, 2016). Ekosistem mangrove berperan dalam memberikan jasa lingkungan dalam penyimpanan karbon yang berdampak baik bagi lingkungan dan manusia. Dampak pemanasan global karena meningkatnya konsentrasi gas-gas di atmosfir seperti $\mathrm{CO}_{2}$ akan mempengaruhi peningkatan temperatur bumi. Peningkatan ini mengakibatkan iklim global berubah seperti perubahan curah hujan dan naiknya intensitas frekwensi badai, naiknya pasang surut laut akibat memuainya air laut pada temperatur yang lebih tinggi. Dampak pemanasan globail lainnya seperti, es abadi akan mencair di kawasan kutub bumi, salinitas menurun dan sedimentasi meningkat di kawasan pesisir dan lautan, sehingga semakin mengancam keberlanjutan sumber daya alam pesisir dan laut sebagai penyangga kehidupan manusia (Latuconsina, 2010).

Artikel ini bertujuan untuk mengulas pentingnya ekosistem mangrove dalam mitigasi bencana khususnya bencana pemanasan global.

\section{METODE}

Artikel ini merupakan suatu kajian berdasarkan pustaka dari berbagai ragam sumber. Pembahasan mendalam dilakukan guna menghubungkan segala peranan dan dampak mangrove bagi lingkungan dan manusia. Windiani (2010) menyatakan hutan merupakan sumber daya alam yang mempunyai multi fungsi sangat penting bagi kehidupan. Manusia merupakan agen yang memanfaatkan sumber daya alam. Pemanfaatan sumber daya alam oleh manusia akan menimbulkan perubahan terhadap ekosistem yang akan mempengaruhi kelestarian sumber daya alam itu sendiri. Senoaji dan Hidayat (2016) menyatakan bahwa hutan mangrove merupakan salah satu hutan yang memiliki peranan besar terhadap perubahan global. Peranan mangrove sebagai mitigasi pemanasan global yang menjadikan indikator untuk melakukan konservasi terhadap ekosistem mangrove. Kajian yang dilakukan dengan mengintegrasikan berbagai pustaka terkini dalam memperkaya informasi. Kata kunci dalam penelusuran pustaka berdasarkan kata: mangrove, pemanasan global, dampak.

\section{PEMBAHASAN}

\section{A. Pengertian Mangrove, Tempat Hidup Dan Syarat Hidupnya}

Pengertian diartikan berbeda- beda menurut para ahli. Mangrove di definisikan menurut sebagai tumbuhan yang terdapat di daerah pasang surut maupun sebagai komunitas (Tomlinson, 1986; Wightman, 1989). Menurut Saerang (1983) mangrove juga didefinisikan sebagai formasi tumbuhan daerah litoral yang khas di pantai daerah tropis dan sub tropis yang terlindung. Sementara itu Soerianegara (1987) mendefinisikan hutan mangrove sebagai hutan yang terutama tumbuh pada tanah lumpur aluvial di daerah pantai dan muara sungai yang dipengaruhi pasang surut air laut, dan terdiri atas jenis-jenis pohon Aicennia, Sonneratia, Rhizophora, Bruguiera, Ceriops, Lumnitzera, Excoecaria, Xylocarpus, Aegiceras, Scyphyphora dan Nypa. Pada intinya mangrove merupakan vegetasi yang tumbuh di daerah pasang surut (Rusila et al, 2006). Ekosistem mangrove atau berupa hutan mangrove dapat didefinisikan sebagai ekosistem hutan dengan faktor fisik yang ekstrem berupa habitat tergenang air dengan salinitas tinggi di pantai dan sungai dengan kondisi tanah berlumpur (Herianto dan Subiandono, 2016).

Setiap jenis hutan memiliki karakteristik lingkungan masing-masing yang terdiri dari tipe tanah, kedalaman, salinitas tanah dan pasang surut. Komunitas hutang mangrove maisng-masing juga menghasilkan komposisi sampah alam, pelepasan kabon dalam siklus daur ulang dan komponen komunitas yang berbeda. Menurut Lugo and Snedaker dalam FAO (1994), mengklasifikasikan mangrove menjadi 6 tipe hutan berdasarkan bentuk, geologi dan siklus hidrologi yaitu:

a. Overwash Mangrove Forest merupakan hutan mangrove yang berada di pulau dengan spesies dominan yaitu mangrove merah. Hutan mangrove ini sering tergenang dan tersiram air pasang, yang mengakibatkan tingginya tingkat ekspor organik. Dan ketinggian pohon maksimum sekitar $7 \mathrm{~m}$.

b. Fringe Mangrove Forest merupakan hutan mangrove yang ditemukan atau hidup di sepanjang perairan atau garis pantai yang memiliki ketinggian lebih tinggi dari tingkat pasang naik rata-rata. Tinggi mangrove maksimum adalah sekitar $10 \mathrm{~m}$.

c. Riverine Mangrove Forest yaitu hutan mangrove yang berada di pinggiran sungai dan sungai pasang surut. Hutan ini memiliki tipe mangrove yang tinggi mencapai $18-20 \mathrm{~m}$.

d. Basin Mangrove Forest ialah hutan mangrove memiliki mangrove betipe kerdil yang terdapat di bagian dalam rawa-rawa. Terdapat jenis mangrove merah di bagian pasang surut. Jenis mangrove pada daerah pedalaman didominasi oleh mangrove putih dan hitam . Tinggi mangrove di hutan ini mencapai $15 \mathrm{~m}$.

e. Hammock Forest umumnya mirip dengan basin mangrove forest dengan ketinggian yang sedikit lebih tinggi dibandingkan dengan daerah sekitarnya. Semua spesies 
mangrove dapat tumbuh tetapi tingginya jarang lebih dari $5 \mathrm{~m}$.

f. Scrub of Dwarf Forest merupakan jenis hutan di pinggiran pantai datar yang berada di Florida Selatan dan Florida Keys. Nutrisi menjadi faktor pembatas pertumbuhan sehingga hanya tumbuh di daerah tersebut dengan tinggi jarang melebihi $1,5 \mathrm{~m}$.

Pertumbuhan dan perkembangan mangrove sangat dipengaruhi oleh lingkungan. Faktor iklim merupakan faktor utama yang mempengaruhi kehidupan mangrove. Faktor-faktor yang mempengaruhi seperti; suhu, angin dan badai, hujan dan zona kehidupan (dearah). Bentuk pertahanan mangrove dalam pertumbuhan merupakan suatu adaptasi dari mangrove terhadap lingkungan. Faktor adaptasi yang berperan dalam pertumbuhan mangrove seperti; letak delta, hidrologi dan drainase, sedimen dan kekeruhan, klasifikasi estuari pantai, akresi dan erosi, pasang surut, salinitas (FAO, 1994).

Menurut Hariphin et al (2016), faktor lingkungan yang dapat mempengaruhi pertumbuhan mangrove meliputi kelembaban substrat (\%), $\mathrm{pH}$ substrat, suhu udara $\left({ }^{\circ} \mathrm{C}\right)$, suhu substrat $\left({ }^{\circ} \mathrm{C}\right)$, dan salinitas (\%o). Perairan dengan nilai $\mathrm{pH}$ 5,6-7,5 termasuk perairan yang produktif, sedangkan perairan dengan $\mathrm{pH} 7,5-8,5$, adalah perairan yang memiliki produktivitas yang sangat tinggi. Suhu udara mangrove untuk dapat tumbuh dengan baik pada suhu rata-rata $>20^{\circ} \mathrm{C}$ dan perbedaan suhu musiman tidak melebihi $5^{\circ} \mathrm{C}$. Suhu berperan penting dalam proses fisiologi seperti fotosintesis dan respirasi. Syarat pertumbuhan lainnya dikemukakan dalam Hamran et al (2014) yaitu syarat pertumbuhan mangrove yang ideal memiliki suhu substrat berkisar $27-31^{\circ} \mathrm{C}$. Suhu substrat sangat membantu dalam proses dekomposisi mineral di habitat mangrove, yang digunakan oleh tanaman mangrove untuk memenuhi kebutuhan energinya selama mengalami pertumbuhan. Salinitas dari lingkungan sekitar mangrove berkontribusi terhadap ketahanan serta jenis mangrove untuk tumbuh di suatu daerah. Perkembangan mangrove ideal memiliki salinitas bervariasi antara 0,5-35\%. Tumbuhan mangrove tumbuh subur di daerah dengan salinitas 10-30 \%o. Salinitas yang sangat tinggi $( \pm 35 \%$ ) berpengaruh buruk, karena dampak negatif tekanan osmotik. Kelembaban substrat dipengaruhi oleh tutupan kanopi sehingga kelembaban substrat lebih stabil. Setiap jenis mangrove memiliki kriteria masing-masing dalam kelembaban substrat yang ideal untuk pertumbuhan dan perkembangannya.

\section{B. Penyebab Kerusakan Ekosistem Mangrove}

Luas hutan mangrove di Indonesia pada Tahun 1999 mencapai 8,60 juta Ha dan yang telah mengalami kerusakan sekitar 5,30 juta Ha. Kondisi kerusakan hutan mangrove di Indonesia dapat dibedakan menjadi hutan mangrove rusak berat mencapai luas $42 \%$, hutan mangrove rusak seluas $29 \%$, hutan mangrove dalam kondisi baik seluas kurang dari $23 \%$ dan hutan mangrove dalam kondisi sangat baik hanya seluas $6 \%$ dari keseluruhan luas mangrove. Berkurangnya luasan ekosistem mangrove alami terjadi seiring meningkatnya kebutuhan manusia yang mendorong deforestasi hutan mangrove untuk memenuhi kebutuhan tersebut (Umayah et al, 2016). Kerusakan mangrove dapat terjadi secara alami atau melalui tekanan masyarakat sekitarnya. Kerusakan ekosistem mangrove secara alami memiliki kadar kerusakan jauh lebih kecil dari pada kerusakan akibat ulah manusia. Kerusakan alami umumnya merupakan siklus alam yang selalu terjadi dan kerusakan tersebut dapat pulih karena alam dapat memperbaiki dirinya sendiri. Kerusakan alami terjadi karena peristiwa alam seperti adanya angin topan atau badai dan iklim kering berkepanjangan yang menyebabkan akumulasi kadar garam dalam tanaman (Ario et al., 2015).

Kerusakan juga diakibatkan oleh ulah manusia karena banyaknya aktifitas manusia di sekitar kawasan hutan mangrove yang berakibat pada perubahan karakteristik fisik dan kimiawi disekitar habitat mangrove. Perubahan tersebut membuat hutan mangrove tidak lagi sesuai bagi kehidupan dan perkembangan flora dan fauna hutan mangrove (Ario et al., 2015). Terdapat dua jenis tekanan utama yang menjadi penyebab terjadinya degradasi hutan mangrove, yaitu tekanan ekstemal dan tekanan internal. Tekanan ekstemal adalah tekanan yang datang dari luar ekosistem mangrove itu sendiri, seperti konversi hutan mangrove menjadi pemukiman, industri atau rekreasi. Tekanan internal adalah tekanan mangrove yang bersumber dari masyarakat sekitar hutan mangrove untuk memanfaatkan ekosistem (Arizona et al., 2009). Perubahan alih fungsi lahan dan pemanfaatan kayu mangrove untuk berbagai keperluan, pembuatan tambak, pemukiman, dan sebagainya merupakan kerusakan yang diakibatkan ulah manusia (Ario et al, 2015). Tingkat kerusakan ekosistem mangrove menjadi sangat cepat akibat pencemaran lingkungan, reklamasi dan sedimentasi dan lainnya (Setyawan dan Winarno, 2006).

Konversi atau perubahan alih fungsi lahan mangrove diperuntukkan sebagai tempat pemukiman terus meningkat seirama dengan meningkatnya populasi serta pesatnya pembangunan. Masyarakat cenderung melirik hutan mangrove untuk mendirikan rumah. Keterbatasan lahan untuk pemukiman khususnya di wilayah yang berpenduduk padat menjadikan alasan masyarakat untuk melakukan alih fungsi hutan mangrove. Kerusakan lahan mangrove semakain diperparah dengan adanya pemanfaatan mangrove sebagai bahan bangunan. Masyarakat yang bertepat tinggal di sekitar hutan mangrove cenderung akan 
menggunakan batang pohon mangrove untuk membangun rumah (Pramudji, 2000).

Konversi lahan mangrove yang diperuntukan sebagai lahan pertanian dan pertambakan dalam usaha memenuhi kebutuhan hidup. Pembukaan lahan mangrove (clear cutting) menyebabkan lahan tersebut menimbulkan berbagai masalah, antara lain lingkungan yang asin, kandungan pirit $\left(\mathrm{FeS}_{2}\right)$ yang tinggi, kondisi yang anaerob dan akibatnya lahan ini menjadi rusak. Terbukanya lahan mangrove juga akan menyebabkan proses oksidasi mengeluarkan asam sulfat, sehingga tanah menjadi sangat asam dan mengandung banyak garam terlarut. Kondisi seperti yang diuraikan di atas, dampaknya adalah menyebabkan lahan tersebut tidak cocok untuk pertambakan dan pertanian (misalnya padi) tidak tumbuh atau produktivitasnya sangat rendah. Tingginya kandungan pirit dalam substrat juga akan menjadi masalah dalam perikanan tambak (Pramudji, 2000).

Erosi dan sedimentasi merupakan salah satu kerusakan alami. Besarnya kerusakan yang terjadi dipercepat oleh dampak dari aktivitas konversi lahan mangrove yang terus meningkat. Peningkatan kerusakan secara tidak langsung mengakibatkan terjadinya pengikisan di sepanjang pantai (Arizona et al, 2009). Laju sedimentasi yang semakin cepat mengakibatkan banyak timbunan sampah serta pencemaran lainnya yang tidak terurai kemudian terakumulasi dan ikut mencemari ekosistem mangrove (Pattipeilohy, 2014)

\section{Peran Ekosistem Mangrove Bagi Manusia: Peran Pelindung Pantai, Perikanan, Hidrologi, Dan Simpanan Karbon}

Mangrove memiliki manfaat yang luas secara biogeokimia lingkungan dan sosial ekonomi masyarakat. Kekayaan manfaat dari ekosistem mangrove juga berhubungan dengan fungsi fisik sebagai mitigasi bencana. Menurut Saparinto dalam Baderan (2017) hutan mangrove secara fisik dapat berfungsi menjaga garis pantai agar tetap stabil, melindungi pantai dan tebing sungai dari proses abrasi, meredam dan menahan hempasan badai tsunami, sebagai kawasan penyangga proses intrusi atau rembesan air laut ke darat. Peranan mangrove menurut Senoaji dan Hidayat (2016) yaitu mangrove sebagai penahan lumpur dan perangkap sedimen yang diangkut oleh aliran air permukaan, pencegah intrusi air laut ke daratan, serta dapat menjadi penetralisir pencemaran perairan pada batas tertentu.

Ekosistem mangrove memiliki manfaat biologis dalam produktivitas penyedia makanan berlimpah bagi berbagai jenis hewan laut dan menyediakan tempat berkembang biak, memijah dan membesarkan anak bagi beberapa jenis ikan, kerang, kepiting dan udang. Secara tidak langsung kehidupan manusia tergantung pada keberadaan ekosistem mangrove pada wilayah pesisir. Berbagai jenis ikan baik yang bersifat herbivora, omnivora maupun karnivora hidup mencari makan di sekitar mangrove terutama pada waktu air pasang. Pengurangan hutan mangrove tentu akan menurunkan produktivitas perikanan tangkap (Kariada dan Irsadi, 2014). Ketersediaan hewan laut yang dapat di konsumsi tentunya akan memberikan manfaat secara social maupun ekonomi bagi masayarakat sekitar.

Hutan mangrove memiliki peranan dalam sistem hidrologi Daerah Aliran Sungai (DAS) maupun siklus hidrologi daerah pesisir. Kawasan hutan mangrove yang berada di tepian sungai berfungsi sebagai penyangga tata air daerah hilir (Windiani, 2010). Mangrove memiliki toleransi yang tinggi terhadap logam berat yang dalam jumlah besar. Zat pencemar yang ada diperairan akan diserap mangrove sehingga kualitas air bagi makhluk hidup menjadi baik dan konsentrsai zat pecemar dalam hewan laut sedikit. Mangrove juga merupakan tempat hidup berbagai jenis gastropoda, kepiting pemakan detritus, dan bivalvia pemakan plankton sehingga akan memperkuat fungsi mangrove sebagai biofilter alami (Kariada dan Irsadi, 2014).

Keseimbangan ekologi lingkungan perairan pantai akan tetap terjaga apabila keberadaan mangrove dipertahankan karena mangrove dapat berfungsi sebagai biofilter, agen pengikat dan perangkap polusi baik perairan maupun udara (Mulyadi et al., 2010). Fungsi kimia, sebagai proses daur yang menghasilkan oksigen, menyerap karbon dioksida serta menyimpan karbon (Baderan, 2017). Fungsi optimal mangrove dalam penyerapan karbon mencapai 77,9\% (Heriayanto dan Subiandono, 2016). Rosot karbon dioksida berhubungan erat dengan biomassa tegakan. Hasil penelitian menunjukkan bahwa ekosistem mangrove memiliki peranan yang penting dalam mengurangi efek gas rumah kaca sebagai mitigasi perubahan iklim karena mampu mereduksi $\mathrm{CO}_{2}$ melalui mekanisme "sekuestrasi", yaitu penyerapan karbon dari atmosfer dan penyimpanannya dalam bentuk biomassa yang mencapai 296 ton C/ha (Rahman et al., 2017). Selama pohon atau tegakan itu hidup, maka proses penyerapan karbon dioksida dari atmosfer terus berlangsung.

\section{Dampak Kerusakan Mangrove Terhadap Global Warming}

Biomassa hutan sangat relevan dengan isu perubahan iklim. Biomasa hutan berperan penting dalam siklus biogeokimia terutama dalam siklus karbon. Keseluruhan karbon hutan, sekitar 50\% diantaranya tersimpan dalam vegetasi hutan. Sebagai konsekuensi, jika terjadi kerusakan hutan, kebakaran, pembalakan d sebagainya akan menambah jumlah karbon di atmosfer (Sutaryono, 2009). Karbon dioksida merupakan salah satu emisi yang dihasilkan dari berbagai aktivitas. Gas karbon 
dioksida bersifat dapat menyerap radiasi infra merah. Konsentrasi karbondioksida yang terus meningkat dapat membuat radiasi yang dipancarkan oleh bumi tidak dapat lepas ke angkasa luar sehingga terperangkap di bumi. Kondisi terperangkapnya radiasi di bumi dapat membentuk efek rumah kaca yang mengakibatkan perubahan iklim. Karbon dioksida masuk ke dalam atmosfer dapat berasal dari dua sumber yaitu sumber alami dan buatan. Sumber alami tergolong penting meliputi proses pernafasan makhluk hidup di bumi serta bahan organik. Sumber buatan dapat meliputi pembakaran bahan bakar fosil, industri, pembakaran hutan dan perubahan tata guna lahan. Konsentrsai karbon dioksida di udara akan terus meningkat dari tahun ke tahun sebesar $1,8 \mathrm{ppm}$ atau $0,5 \%$ tiap tahunnya (Ravindranat, 2008).

Bentang mangrove memiliki arti penting bagi iklim global (Sigit, 2014). Hutan mangrove berpotensi menyerap karbon lebih banyak dibandingkan dengan tumbuhan lainnya karena mangrove dikategorikan sebagai hutan lahan basah. Kemampuan mangrove dalam menyimpan karbon dapat mengurangi peningkatan emisi karbon di alam. Penelitian pendukung dilakukan oleh tim peneliti dari US Forest Service Pasifik Barat Daya dan Stasiun Penelitian Utara, Universitas Helsinki dan Pusat Penelitian Kehutanan International menemukan bahwa mangrove per hektar dapat menyimpan karbon empat kali lebih besar dari pada hutan tropis lainnya di seluruh dunia (Baderan, 2017).

Penyelamatan mangrove dapat menurunkan emisi karbon Indonesia ke tingkat 26\% (41\% jika ada komitmen bantuan Internasional) pada tahun 2020. Indonesia sendiri memiliki 3,1 juta ha mangrove atau hampir seperempat kawasan mangrove yang ada di dunia yang sangat berpotensi sebagai penyerap karbon di ekosistem pesisir. Menurut Daniel Murdiyarso, peneliti iklim dari Pusat Penelitian Hutan Internasional (CIFOR, 2014), satu hektar mangrove mampu untuk menyerap antara 600-1800 ton karbon atau jika digunakan rataan maka 1.200 ton karbon dapat dipertahankan dalam 1 hektar bentang hutan mangrove. Jika mangrove di Indonesia 3,1 juta ha, sekurang-kurangnya 3 miliar metrik ton karbon dapat diselamatkan untuk tidak terlepas sebagai emisi ke udara. Kehilangan hutan mangrove maka akan melepaskan karbon dioksida dalam jumlah besar sebanding dengan karbon yang telah diserap (Sondak, 2015). Deforestasi atau kerusakan mangrove dapat menyebabkan peningkatan dari emisi karbon dioksida $20 \%\left(\mathrm{CO}_{2}\right)$ di atmosfer (Prasetyo et al, 2017).

\section{E. Dampak Global Warming bagi Kehidupan Manusia}

Perubahan iklim ditandai dengan akibat adanya lubang ozon yang berarti sinar UV memancarkan sinarnya secara langsung, tanpa adanya penyaring (lapisan ozon). Semua mahkluk hidup di bumi tidak akan mampu bersentuhan langsung dengan sinar UV tersebut. Cahaya matahari yang kita terima atau rasakan setiap hari, sudah merupakan hasil penyaringan dari ozon, sehingga sudah tidak berbahaya lagi bagi manusia dan mahkluk hidup lainnya di muka bumi (Samidjo dan Suharso, 2017). Hasil pengukuran para ilmuan telah membuktikan terjadinya peningkatan sinar ultraviolet-B ke permukaan bumi sebanyak $30 \%$, yang berdampak buruk terhadap manusia dan makhluk hidup lainnya (Latuconsina, 2010). Dampak perubahan iklim yang sangat dirasakan adalah terjadinya peningkatan suhu, peningkatan curah hujan dan terjadinya perubahan iklim ekstrim. Perubahan iklim ini akan berpengaruh terhadap kesehatan manusia baik secara langsung maupun secara tidak langsung (Raksanagara et al, 2015).

Perubahan iklim secara langsung akan berdampak negatif bagi kesehatan manusia terutama yang berhubungan dengan kejadian penyakit, terutama penyakit yang ditularkan oleh vektor seperti demam berdarah. Efek perubahan iklim yang tidak langsung terhadap kesehatan manusia adalah melalui penyakit yang ditularkan serangga dan hewan pengerat-menular (misalnya, malaria, demam berdarah, virus demam west nile, penyakit lyme dan hantavirus pulmonary syndrome); meningkat asap dan polusi udara; penyakit yang ditularkan melalui air dan makanan yang berhubungan dengan penyakit (misalnya, giardiasis, infeksi e. coli, dan keracunan kerang); radiasi ultra violet kuat yang dapat menyebabkan kanker kulit dan katarak. Berdasarkan data WHO pada tahun 2003, dilaporkan bahwa terjadinya perubahan iklim berperan dalam terjadinya penyakit diare sebesar $2,4 \%$ dan penyakit malaria sebesar $2 \%$. Pada tahun 2000, WHO menduga bahwa sekitar 150.000 kematian disebabkan oleh perubahan iklim (Raksanagara et al, 2015).

Pola iklim yang terganggu juga menyebabkan efek tidak langsung terhadap kesehatan manusia. Efek terhadap pola hujan yang meningkatkan bencana banjir dapat menyebabkan peningkatan kejadian penyakit perut karena efeknya pada sumber air dan penyediaan air bersih, penyakit malaria, demam berdarah dengue, chikungunya dan penyakit lainnya yang ditularkan melalui rodent seperti leptospirosis (Keman, 2007). Perubahan temperatur, kelembaban udara, dan curah hujan yang ekstrem mengakibatkan nyamuk lebih sering bertelur sehingga vektor yang tertularkan penyakit pun bertambah (Triana, 2008).

Kondisi iklim yang tidak stabil dapat juga menyebabkan peningkatan kejadian bencana alam, seperti badai, angin siklon puting beliung, kekeringan, dan kebakaran hutan, yang berdampak terhadap kesehatan fisik dan mental masyarakat yang terserang. Efek tidak secara langsung ini 
menjadi sangat serius pada daerah di dunia dengan penduduk miskin (Keman, 2007). Perubahan iklim yang tidak menentu akibat dari pemanasan global sudah banyak dirasakan saat ini. Beberapa daerah di Indonesia telah mengalami curah hujan yang sangat rendah sehingga terjadi krisis air (kekeringan). Sedangkan di daerah lainnya malah curah hujan yang sangat tinggi, sehingga terjadi banjir dan tanah longsor (Samidjo dan Suharso, 2017).

\section{F.Upaya Konservasi Mangrove Sebagai Salah Satu Bentuk Mitigasi Global Warming}

Peranan hutan mangrove dalam penyimpanan karbon sangat berpengaruh terhadap global warming. Kerusakan hutan mangrove yang semakin meningkat akan memberikan dampak besar terhadap percepatan perubahan dunia. Upaya yang dilakukan sebagai mitigasi global warming melalui pendekatan masyarakat, pemulihan hutan dengan penanaman, pembangunan pelindung pantai, dan pendekatan ekonomi.

Kerusakan mangrove dapat dicegah dengan adanya keterlibatan masyarakat dalam proses rehabilitasi lahan. Kegiatan rehabilitasi akan berdampak langsung pada masyarakat sekitar mangrove. Hal ini dapat diketahui dengan melakukan kajian melalui komunikasi yang efektif pada masyarakat (Umayah et al., 2016). Keterlibatan masyarakat dalam reabilitasi lahan dapat meningkatnya kesadaran masyarakat akan peranan mangrove dan keberhasilan rencana. Masyarakat yang sadar akan peranan hutan mangrove akan memberikan dampak berkurangnya kerusakan pada hutan mangrove.

Penanaman mangrove merupakan salah satu upaya untuk mengembalikan hutan mangrove. Upaya penanaman secara perlahan akan berangsurangsur memperbaiki hutan mangrove. Penanaman mangrove sebaiknya dilakukan berdasarkan kondisi lingkungan. Setiap mangrove memiliki kriteria rona lingkungan untuk tumbuh. Jenis mangrove yang sesuai dengan kondisi lingkungan dapat meningkatkan kesuksesan uoaya yang dilakukan dan mempercepat pemulihan suatu ekosistem (Novianty, 2012).

Merehabilitasi habitat hutan mangrove memerlukan peningkatan bangunan pelindung pantai dan pesisir. Penyesuaian RTRW pesisir dan laut terhadap perubahan kondisi (lahan, infrastruktur, sosial dan lingkungan (Swedi, 2005). Peningkatan pelindung pantai adan pesisir perlu dilakukan sebelum proses rehabilitasi atau penanaman mangrove kembali. Pembangunan breakwater merupakan suatu rekayasa terhadap lingkungan yang berfungsi meredam gelombang. Keberadaan breakwater dapat memberikan kesempatan bagi mangrove untuk tumbuh dan berkembang (Novianty, 2012).

Upaya konservasi lainnya guna mengurangi laju degradasi hutan mangrove dapat dirancang mekanisme hutan mangrove sebagai kawasan hutan yang memberikan jasa lingkungan. Jasa lingkungan tersebut berupa potensi hutan mangrove sebagai penyerap karbon yang dapat dijual kepada pihakpihak investor (Dharmawan dan Siregar, 2008). Hutan merupakan ekosistem vegetasi yang didalamnya terjadi interaksi dengan lingkungan, penghasil oksigen dan penghasil biomassa dari pemanfaatan karbon dioksida. Isu perubahan iklim dan pemansan global semakin marak sehingga untuk menanganinya dilakukan mekanisme REDD (Reducing Emision from Deforestation and Degradation) dalam perdagangan karbon International. Hutan alam memiliki potensi yang besar untuk diikutsertakan dalam mekanisme REDD. Indonesai yang berpartisipasi aktif dalam REDD+. Selama ini perhatian untuk mengurangi maupun mencegah emisi telah dilakukan Indonesia sesuai dengan dengan ketentuan REDD+ (Reducing Emissions from Deforestation and Forest Degradation). Belum masuknya soil pool dalam perhitungan TREH hutan mangrove dapat memberikan penilaian rendah (underestimate) terhadap emisi $\mathrm{CO} 2$ yang terlepas akibat deforestasi dan degradasi sekaligus kemampuan hutan mangrove dalam menyerap karbon, sehingga nilai TREH masih perlu disempurnakan. Masuknya soil pool juga dapat memengaruhi tingkat rujukan hutan (TRH) dimana akresi tanah setelah kegiatan restorasi dapat memberikan implikasi pada tingkat serapan karbon di hutan mangrove (Sidik et al., 2017).

\section{KESIMPULAN}

Kondisi kerusakan ekosistem mangrove di Indonesia tergolong rusak berat mencapai luas $42 \%$ dan keadaan rusak seluas $29 \%$ yang melebihi setengah dari ekosistem mangrove yang ada. Kerusakan ekosistem mangrove diakibatkan oleh siklus alam dan aktivitas manusia dalam memenuhi kebutuhan hidup. Dampak kerusakan ekosistem mangrove akan mempengaruhi dari segi ekonomi berupa pendapatan manusia, perubahan prilaku masyarakat dari segi sosial dan kerusakan lingkungan hutan. Kerusakan ekosistem mangrove secara besar akan memberikan efek terhadap adanya global warming yang memperngaruhi iklim untuk keberlangsungan kehidupan makhluk hidup. Upaya yang dilakukan sebagai mitigasi global warming melalui pendekatan masyarakat, pemulihan hutan dengan penanaman, pembangunan pelindung pantai, dan pendekatan ekonomi.

\section{UCAPAN TERIMA KASIH}

Penulis mengucapkan terima kasih kepada Dr. Aji Ali Akbar, M.Si. dan Jumiati, S.Si, M.Si selaku pembimbing dalam penulisan artikel ini. Terima kasih juga kepada rekan-rekan yang telah membantu dalam penulisan artikel ini. Semoga 
penulisan ini dapat bermanfaat dalam pengembangan ilmu pengetahuan.

\section{DAFTAR PUSTAKA}

Ario, Raden; Subardjo, Petrus; Dan Handoyo, Gentur. 2015. Analisis Kerusakan Mangrove Di Pusat Restorasi Dan Pembelajaran Mangrove (Prpm), Kota Pekalongan. Jurnal Kelautan Tropis, 18(2), 64-69.

Arizona, Meivy dan Sunarto. 2009. Kerusakan Ekosistem Mangrove Akibat Konversi Lahan Di Kampung Tobati Dan Kampung Nafri, Jayapura. Jurnal Kerusakan Ekosistem Mangrove, 23(3), 18-39.

Baderan, Dewi Wahyuni K. 2017. Distribusi Spasial dan Luas Kerusakan Hutan Mangrovedi Wilayah Pesisir Kwandang Kabupaten Gorontalo Utara Provinsi Gorontalo. Jurnal Geoeco, 3(1), 1-8.

Baderan, Dewi Wahyuni K. 2017. Serapan Karbon Hutan Mangrove Gorontalo. Edisi Pertama. Cetakan Pertama. CV. Budi Utama. Yogyakarta.

Dharmawan, I.W.S., dan Siregar, C.A., 2011. Karbon Tanah dan Pendugaan Karbon Tegakan Avicennia marina (Forsk) Vierh di Ciasem, Purwakarta. Jurnal Penelitian Hutan dan Konservasi Alam, 5(4), 317-328.

Hariphin; Linda,Riza; dan Lovadi, Irwan. 2014. Analisa Vegetasi Mangrove Di Desa Sebubus Kecamatan Paloh Kabupaten Sambas. Jurnal Protobiont, 3(2), 201-208.

Hariphin; Linda,Riza; Dan Rusmiyanto,Elvi. 2016. Analisis Vegetasi Hutan Mangrove Di Kawasan Muara Sungai Serukam Kabupaten Bengkayang. Jurnal Protobiont, 5(3), 66-72.

Herianto dan Subiandono, Endro. 2016. Peran Biomasa Mangrove Dalam Menyimpan Karbon Di Kubu Raya, Kalimantan Barat. Jurnal Analisis Kebijakan, 13(1), 1-12.

Kariada, Nana Dan Irsadi, Andin. 2014. Peranan Mangrove Sebagai Biofilter Pencemaran Air Wilayah Tambak Bandeng Tapak, Semarang. Jurnal Manusia Dan Lingkungan, 21(2), 188-194.

Keman,Soedjajadi. 2007. Perubahan Iklim Global, Kesehatan Manusia Dan Pembangunan Berkelanjutan. Jurnal Kesehatan Lingkungan, 3(2), 195 - 204.

Keputusan Menteri Lingkungan Hidup Nomor 201 Tahun 2004. Tentang Kriteria Baku dan Pedoman Penentuan Kerusakan Mangrove.

Latuconsina, Husain. 2010. Dampak Pemanasan Global Terhadap Ekosistem Pesisir Dan Lautan. Jurnal Ilmiah Agribisnis Dan Perikanan (Agrikan Ummu-Ternate), 3(1), 30-37.
Mulyadi, Edi; Hendriyanto, Okik; Dan Fitriani, Nur. 2010. Konservasi Hutan Mangrove Sebagai Ekowisata. Jurnal Ilmiah Teknik Lingkungan, 1(Edisi Khusus), 51-58.

Pattipeilohy, Mery. 2014. Fenomena Pendangkalan Zona Pasang Suruthutan Mangrove Teluk Dalam Ambonserta Upaya Pengembangan Ekowisata. Jurnal Pena Sains, 1(2), 56-63.

Pramudji. 2000. Dampak Perilaku Manusia Pada Ekosistem Hutan Mangrove Di Indonesia. Journal Of Oseana, 25(2), 13-20.

Prasetyo, Dimas Panji Budi; Nuraini, Ria Azizah Tri dan Supriyantini. 2017. Estimation Carbon Stock n Mangrove Vegetation at Mangrove Area of Ujung Piring Jepara District. International Journal of Marine and Aquatic Resource Concervation and Co-existence, 2(1), 38-45.

Rachmawati, Ditha; Setyobudiandi, Isdradjad; dan Hilmi, Endang. 2014. Potensi Estimasi Karbon Tersimpan Pada Vegetasi Mangrove Di Wilayah Pesisir Muara Gembong Kabupaten Bekasi. Jurnal Omni-Akuatika, 13(19), 85 - 91.

Rahma, Fajar; Basri, Hairul; dan Sufardi. 2015. Potensi Karbon Tersimpan Pada Lahan Mangrove Dan Tambak Di Kawasan Pesisir Kota Banda Aceh. Jurnal Manajemen Sumberdaya Lahan, 4(1), 527-534.

Raksanagara, Ardini S; Arisanti, Nita; Dan Rinawan, Fedri. 2015. Dampak Perubahan Iklim Terhadap Kejadian Demam Berdarah Di Jawa Barat. Jurnal Sarjana Kedokteran, 1(1), 43-47.

Rusila Noor, Y., M. Khazali, dan I N.N. Suryadiputra. 2006. Panduan Pengenalan Mangrove di Indonesia. Edisi Pertama. Cetakan Kedua. PHKA/WI-IP. Bogor.

Rahman; Effendi, Hefni; dan Rusman, Iman. 2017. Estimasi Stok dan Serapan Karbon pada Mangrove di Sungai Tallo, Makassar. Jurnal Ilmu Kehutanan, 1(1), 19-28.

Ravindranat, Ostwald. 2008. Carbon Inventory Methods : Handbook For Greenhouse Gas Inventory, Carbon Mitigation and Roundwood Production Project. Switzerland : Springer Science and Business Media B.V.

Samidjo, Jacobus dan Suharso, Yohanes. 2017. Memahami Pemanasan Global dan Perubahan Iklim. Jurnal Ilmiah, 24(2), 1-10.

Senoaji, G dan Hidayat, Muhamad Fajrin.2016. Peranan Ekosistem Mangrove Di Pesisir Kota Bengkulu Dalam Mitigasi Pemanasan Global Melalui Penyimpanan Karbon. Jurnal Manusia Dan Lingkungan, 23(3), 327-333.

Setyawan, Ahmad Dwi Dan Winarno, Kusumo. 2006. Permasalahan Konservasi Ekosistem Mangrove Di Pesisir Kabupaten Rembang, Jawa Tengah. Jurnal Biodiversitas, 7(2), 159163. 
Sidik, Frida; Supriyanto, Bambang dan Lugina, Mega. 2017. Tingkat Rujukan Emisi Hutan Mangrove Delta Mahakam. Jurnal Analisis Kebijakan Kehutanan, 14(2), 93-104.

Sondak, Calvyn, F.A. 2015. Estimasi Potensi Penyerapan Karbon Biru (Blue Carbon) oleh Hutan Mangrove Sulawesi Utara. Journal of Asean Studies On Maritime Issues, 1(1), 2429.

Sutaryono, Dandun. 2009. Perhitungan Biomassa. Wetlands International Indonesia Programme. Bogor.

Swedi, Nawa. 2005. Upaya Pencegahan dan Penanggulangan Dampak Pemanasan Global. Jurnal Teknik Lingkungan, 6(2), 397-401.

Triana, Vivi. 2008. Pemanasan Global. Jurnal Kesehatan Masyarakat, 2(2), 159-163.

Umayah, Sari; Gunawan, Haris; dan Isda, Mayta Novaliza. 2016. Tingkat Kerusakan Ekosistem Mangrove Di Desa Teluk Belitung Kecamatan Merbau Kabupaten Kepulauan Meranti. Jurnal Riau Biologia, 1(4), 24-30.

Windani. 2010. Strategi Pemberdayaan Masyarakat Di Kawasan Hutan Sebagai Langkah Antisipatif Dalam Penanganan Bencana Banjir Dan Tanah Longsor Di Kabupaten Trenggalek. Jurnal Sosial Humaniora, 3(1), 148-161. 